University of Baghdad

College of Engineering

$\int \in$

(U)

JOURNAL OF ENGINEERING
Journal of Engineering

journal homepage: www.joe.uobaghdad.edu.iq

Number 11 Volume 27 November 2021

Water Resources and Surveying Engineering

\title{
Assessing of the Morphology and Sediment Transport of Diyala River
}

\author{
Wafeek Abood Jassam * \\ M.Sc. student \\ University of Baghdad-College of Engineering \\ Baghdad, Iraq \\ w.jassam1310@coeng.uobaghdad.edu.iq
}

\author{
Basim Sh. Abed \\ Asst. Prof. \\ University of Baghdad-College of Engineering \\ Baghdad, Iraq \\ bassim.shabaa@coeng.uobaghdad.edu.iq
}

\begin{abstract}
Diyala River is one of the important rivers that provide water for the Governorate of Diyala. In this research, the morphology and sediment transport of this river were studied using HEC-Ras software. The selected length of the river in the present study is $193 \mathrm{~km}$ and extended from Diyala Weir to the confluence of Tigris River and Diyala River. The fieldwork period extended from June 2020 till August 2020, where suspended-load and bed-load samples were collected and surveyed some cross-sections. The one-dimensional sediment transport model has been calibrated for five years, from 2014 to 2019. The results were compared with the measured cross-sections in 2019, and the suitable value of (maximum depth) was $120 \mathrm{~cm}$ for five years. The result of invert change from the simulation of the sediment model for real condition of the river from 2018 to 2019 ranged from $0.2 m$ to $0.6 m$.

Moreover, the daily and yearly sediment discharge was equal to 227.7 tons/day and 83531.93 tons/year, which were previous studies carried out on this river. While the simulating results of the imposed period as five successive flood years give an invert change values varied from -1.25 to $1.4 \mathrm{~m}$. The river's capacity was improved by rising the riverbank level for parts of the reach and/or training of cross-sections for other parts.
\end{abstract}

Keywords: Diyala River, Capacity improvement ,HEC-RAS software, Sediment transport model.

*Corresponding author

Peer review under the responsibility of University of Baghdad.

https://doi.org/10.31026/j.eng.2021.11.04

2520-3339 @ 2019 University of Baghdad. Production and hosting by Journal of Engineering.

This is an open access article under the CC BY4 license http://creativecommons.org/licenses/by /4.0/).

Article received: 21/3/2021

Article accepted: $1 / 5 / 2021$

Article published:1/11/2021 


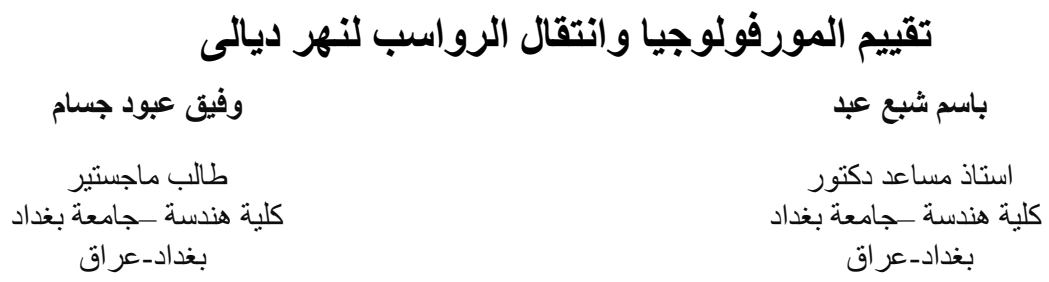

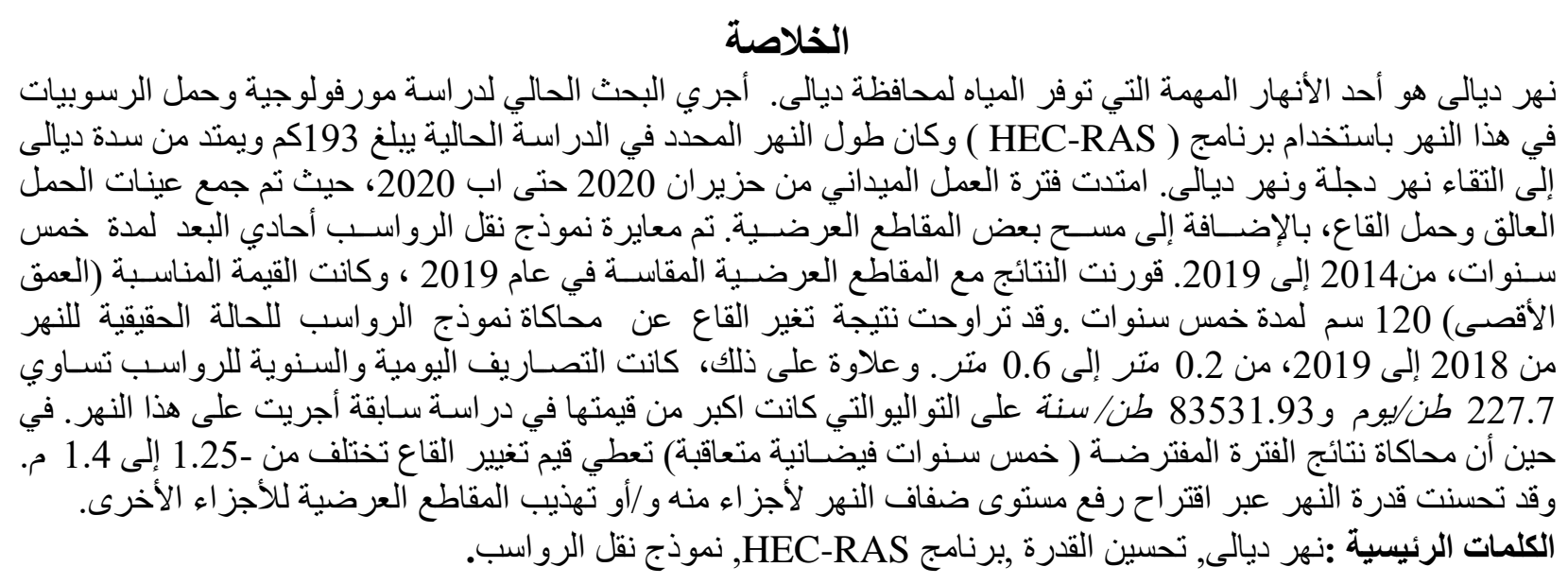

\section{INTRODUCTION}

The decreasing of flowrate in Diyala River, downstream of Diyala weir during the past dry years, after the flood of 1988, as well as the accumulation of sediment in the stream of the river for long periods due to the lack of maintenance in the river, led to a major change in the morphology of this river, which caused a reduction in the capability of the river to passes the flood waves. That issue presented clearly with the flood of 2019, which reflected the reduction of the flow capacity in Diyala River, especially within Baqubah City. Therefore, there is a very need for a study that must be carried out for the hydraulic analysis and estimation of the sediment load in the river to define their effects and reduce the risk of flooding in Baqubah City. Diyala River is the fifth branch of the Tigris River that consists of the confluence of the Sirwan and Tangro rivers in Darbandikhan Lake in the Sulaymaniyah Governorate in northern Iraq. Diyala River has a total length of $445 \mathrm{~km}$. The selected length for the river in the present study was $193 \mathrm{~km}$ and extended from Diyala Weir to the confluence end of Tigris River and Diyala River, Fig.1. Multiple studies used HEC-RAS software to simulate the sediment in the rivers and evaluate the sediment quantity. Some of the studies also used other methods to estimate the value of sediment accumulation within the rivers. This part will present these studies. (Al-Ansari, et al., 1986) estimated the suspended sediment quantity lower of Diyala River. The selected river reach of the river extended from the Hemrin reservoir to downstream of Diyala Weir with a length equal to $50 \mathrm{~km}$. The period of sediment sampling extended from June 1984 to May 1985. The total number of the collected sediment samples from the Hemrin station was equal to 314 samples. The study results showed the value of annual suspended sediment quantity was equal to 64589 tonnes and the annual quantity of solute load was equal to $1.24 \times 10^{6}$ tonnes. The average value of daily sediment discharge was equal to 178.6 tons/day. While the mean value of monthly sediment discharge was 5335 tons/month, and the yearly sediment discharge was 64022.5 tons/year in Diyala River. (Azarang, et al., 2015) developed one-dimensional Version 4.1 of the HEC-RAS model to predict the reservoir dam's 
ability to protect the Karkheh River, located in Iran, by simulating erosion and sedimentation downstream of the river. The length of the Karkheh River is $94 \mathrm{~km}$ divided into 138 sections and the distance between cross-sections was $680 \mathrm{~m}$, the period of sampling was 12 years from 2001 till 2013. According to the sediment results (Ackres-White, Larsen, and Engelund-Hansen) formulas had an accurate prediction of sediment transport and erosion in the Karkheh River since the NashSutcliffe criterion values between 0.62 to 0.75 . (Mustafa, et al., 2017) carried out a study to estimate the sediment transfer for the Euphrates River from the downstream of the Haditha dam to the Heet station by implementing the HEC-RAS software version 4.1, and model was calibrated and validated, the evaluated value of Manning Coefficient $(\mathrm{n}=0.033)$. The sediment load amount at the Heet city station was equal to (551,76 tonnes/day) which was considered to be less than the deposit value in a study measured in 1988 which was equal to $(189,041$ tonnes/day) because the discharge was increased in that area. (Kayyun and Dagher, 2018) reviewed the Tigris Rivers sediment analysis that was carried out using the HEC-RAS software version 5.03 for the area between the Saray station and the Muthanna bridge in the Baghdad City. The study used a sediment function called Lorsen Copeland, as well as a new equation for the river water surface level upstream and downstream of the river was developed. The study also included the river bed change estimated for the period 2012-2017, which was found to be equal to $0.39 \mathrm{~m}$ (sedimentation), 0.15 (erosion) $m$. The average depth of erosion was $1 \mathrm{~m}$ from 2017 to 2040 when the discharge value was $461 \mathrm{~m}^{3} / \mathrm{sec}$. (Daham, and Abed,2020) used HEC-RAS, version 5.0.4 to develop a numerical model that simulates the transportation of sediment in the upstream part of the Gharraf River. The data from the ministry of water resources, hydrological and cross-sectional, were used to calibrate and verify the model for the range extended from Kut to Hay cities with a distance equal to $58 \mathrm{~km}$. In addition to this, a 5-month field sampling was collected for suspended and bed loads from 7-2-2019, and samples were analyzed in the lab and the results were used to develop the model. The real sediment accumulation in the river was predicted in 2019, and the results of simulating the model for the year 2019, gave a value of accumulated sediment depth ranged from $2.5 \mathrm{~cm}$ to $0.5 \mathrm{~m}$, whereas the depth of erosion ranged from $-4 \mathrm{~cm}$ to $-2 \mathrm{~cm}$. The estimated quantity of sediment during one year ranged from 70 to 1008 Tones/day. To avoid sedimentation or erosion, lining of the selected river-stations with concrete or with grouted riprap respectively.

The main objective of the present study is to simulate a one-dimensional sediment transport model of the lower reach of Diyala River by implementing HEC-RAS software (5.0.7) since there was no previous study concerned with developing a numerical model to estimate sedimentation in the lower part of this river, as in Fig.1. 


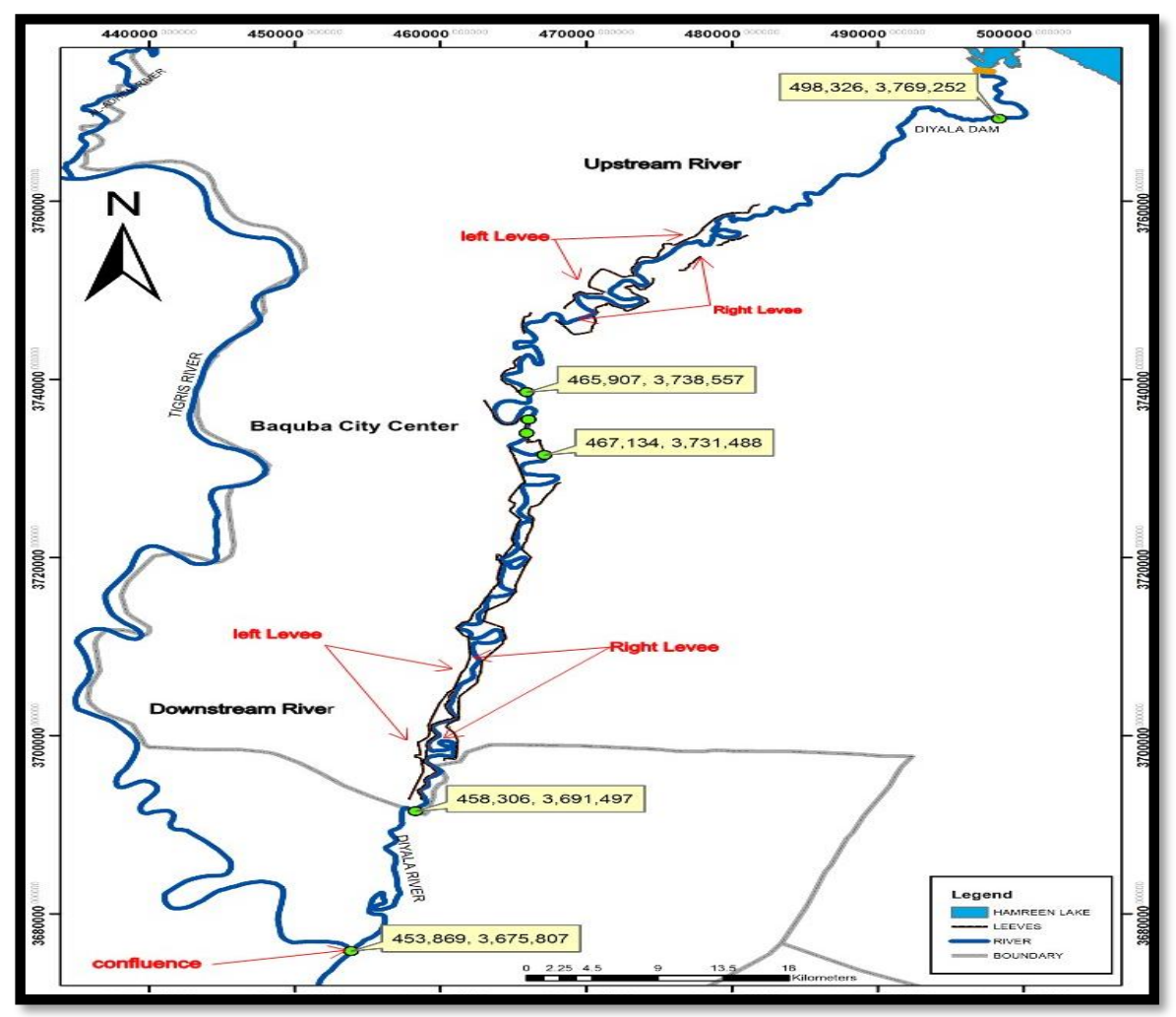

Figure1. The map of the Diyala River, ARC-MAP(10.2).

\section{INPUT DATA AND THE SELECTED BOUNDARY CONDITIONS}

The HEC-RAS software (5.0.7) was released in the United States in 2016 to study natural river analysis by "the Army Corps of Engineers". (Daham, and Abed,2020).

\subsection{One-dimensional Steady Flow Model}

The one-dimensional analysis model was developed by applying accurate formulas. The current study begins at a station 10,000 $m$ when the Diyala river passes into the lower Diyala Weir and ends at a station 203,000 $\mathrm{m}$, at the junction with the Tigris River.

The cross-sectional data used during the simulation were calculated by ( Ministry of Water Resources from 2014 to 2019). The selected distance between every successive cross-section ranges between $100 \mathrm{~m}$ and $1 \mathrm{~km}$. The one-dimensional steady-state model has been calibrated and validated, and the values of the estimated values of Manning roughness for the steady-state were 0.028 and 0.045 for the mainstream and the flood plains of Diyala River, respectively. While (Mustafa, et al., 2016) found that the Manning roughness value for the mainstream of the Diyala River was 0.027, and (Asaad and Abed, 2019) found it is equal to 0.032 for the mainstream of the Tigris River and 0.040 for the floodplain.

\subsection{One-dimensional Quasi Unsteady Flow}

Several sediment transport models had been developed using the quasi-unsteady flow method and by selecting flow series as a boundary condition upstream of Diyala River. To begin with, the model that simulated Diyala River during the period from 1/2/2014 to 1/2/2019, for 67 months, 
with a time interval of 730 hours, and the discharge rate ranged from (1 to 601) $\mathrm{m}^{3} / \mathrm{s}$, the purpose of developing this model is to evaluate the suitable value of the ( $\mathrm{d}$ max., which refer to maximum securing depth that may occur along the river) by testing several values of ( $\mathrm{d}$ max.) to calibrate the sediment transport model.

The other models used the same values of flowrates that represent Diyala River during the high flow condition that ranged from(15 to 601) $\mathrm{m}^{3} / \mathrm{s}$ and $192 \mathrm{~m}^{3} / \mathrm{s}$ as average. Still, the simulation was during different periods: one, two, three, four, and five years. The selected type of boundary condition at the end of the Diyala River was the normal depth with the value of energy slope was evaluated from the river profile and equal to $18 \mathrm{~cm} / \mathrm{km}$. Also, the temperature value in this study was $20^{\circ} \mathrm{C}$ which was measured during the field measurements period (The period in which sediment samples were gathered from the river).

\subsection{The Sediment Transport Model}

Before the sediment transport model can be performed, very critical data must be entered. These include a file of flow geometry, a file for the chosen method of flow, a quasi unsteady flow method, and a file of the sedimentation details. This sediment data file has a transporting function, and the transport function was chosen in this study was "Laursen-Copeland' since Diyala River has a bed type of clayey silt. Also, it contains boundary conditions; the rating curve boundary condition calculates the sediment flowrate and includes the following information: the sediment flowrate, the water discharge, and the upstream grain distribution curve. In this study, the rating curve boundary condition was selected for the upstream of Diyala River that used the data collected during the period of field observation that extended from June 2020 till August 2020. Fifteen samples of suspended sediment were collected, and three sample sets of suspended load at the upstream part of Diyala River were considered as the inputs of deposit concentration discharge at the upstream of the study reach (at C.S . No. 39.97, station $10000 \mathrm{~m}$ ). At the same time, the total number of bed-load samples was five which the analyzing results of these bed samples were used as input data of particle size distribution curves in the sediment file. Fig. 2 shows the particle size distribution curve for the upper part of the river.

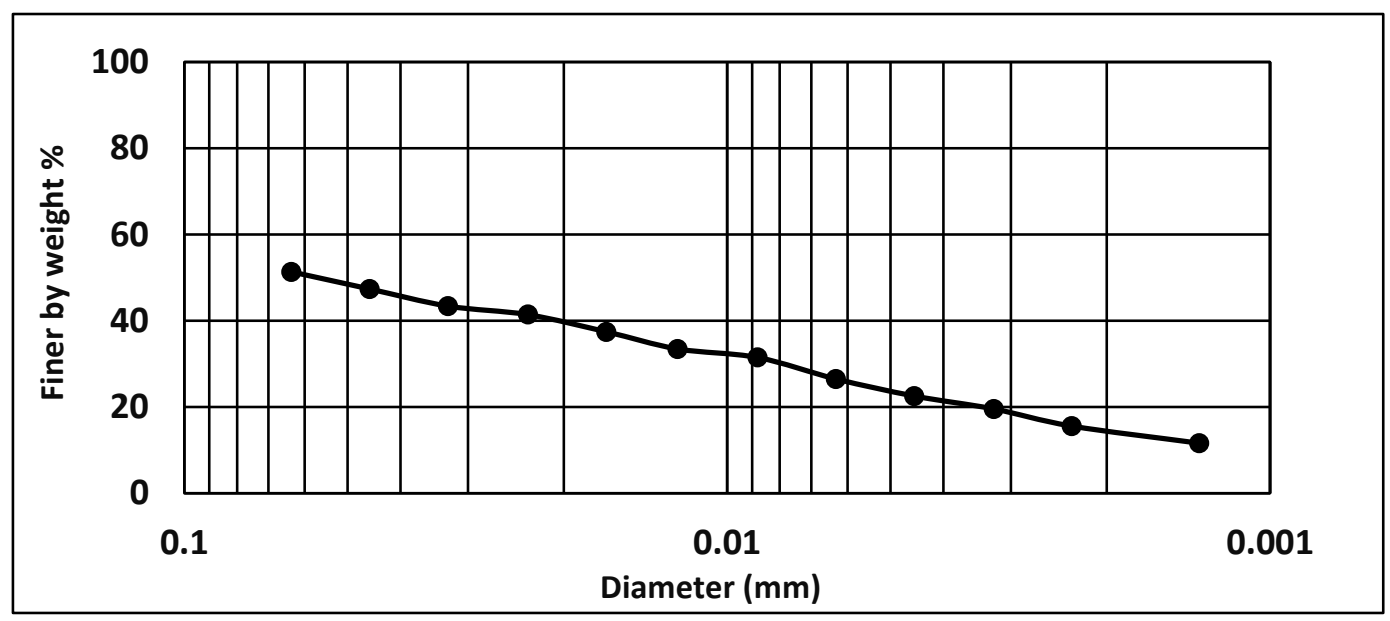

Figure 2. The grain size distribution at the upper part of Diyala River. 


\subsection{Main Governing Equations for Sediment Transport}

There are basic equations developed by (Brunner and Gary, 2016) about the deposit transportation within the river. First of all, the equation of continuity of sediments;

$$
-\frac{\partial q_{s}}{\partial \mathrm{X}}=\left(1-\lambda_{p}\right) \mathrm{b} \frac{\partial \eta}{\partial T}
$$

Where: $\mathrm{b}=$ the width of the river-bed, $m . \eta=$ the river-section height, $m . \lambda_{p}=$ porosity,dimensionless . $q_{s}=$ deposit quantity rate, tones/day. The second equation is the LaursenCopeland sediment transportation formula :

$$
c_{m}=0.01 \gamma\left(\frac{d_{s}}{\mathrm{D}}\right)^{1.167}\left(\frac{\tau_{0}}{\tau_{c}}-1\right) f\left(\frac{u^{*}}{\omega}\right)
$$

Where: $\gamma=$ specific weight of water, $\mathrm{kg} / \mathrm{m}^{3}$. $d_{s}=$ median diameter of deposit particles, $\mathrm{mm}, \mathrm{D}$ $=$ the effective flow depth, $m . \tau_{0}=$ shear stress of river-bed, $p a . \tau_{c}=$ the critical shear stress of riverbed, $p a . \omega=$ fall speed of sediment particle, $\mathrm{m} / \mathrm{s} \cdot \mathrm{u}^{*}=$ the shear speed, $\mathrm{m} / \mathrm{s} . c_{m}=$ the sediment quantity, tones/day.

\section{THE RESULTS OF SEDIMENT MODEL SIMULATION}

The calibration and validation of the sediment transport model are considered the most important procedure to check the accuracy of the sediment model to simulate the actual morphology conditions of Diyala River and present the river state during actual and hypothetical cases.

\subsection{Calibration and Validation of the Sediment Model}

The one-dimensional sediment transport model was calibrated by analysis of several values of maximum sediment accumulation depth along the river per unit time, which were equal to $(40 \mathrm{~cm}$, $80 \mathrm{~cm}, 120 \mathrm{~cm}, 150 \mathrm{~cm}$ ). The model was simulated for the period from 1/2/2014 to 1/2/2019 initially by inputting the cross-sections observed by MoWR in 2014 in the model, and then the model was simulated for five years, to 2019 , using real values of flowrates ranging from (1 to 601) $\mathrm{m}^{3} / \mathrm{s}$ that conducted during those five years. The measured cross-sections by MoWR in 2019 were compared with the resulting cross-sections from the simulation of the sediment model for five years till 2019 to evaluate the suitable value of (maximum depth). Nine stations were chosen to observe the effect of sediment accumulation or erosion in those cross-sections for calibration of the sediment model. The results of calibration showed that the suitable (max. depth) value that represents the river during five years was $120 \mathrm{~cm}$ since, in this value, the measured cross-sections converge with the simulated cross-sections and produce a value of RMSE equal to $0.2 \mathrm{~m}$ and the value of the $\mathrm{R}^{2}$ was equal to 0.87 . Fig. 3 shows some of the calibrated stations along the river.

The sediment transport model was validated by selecting another five stations using the best value of (max. depth), which was $120 \mathrm{~cm}$ for five years. Also, the resulting cross-sections from simulating the model for five years, till 2019, were compared with measured cross-sections in 2019, and the results indicate acceptable values concerning the RMSE and determination coefficient, the values were equal to $0.1 \mathrm{~m}$ and 0.87, respectively. Fig .4 shows some of the validated stations along the river. 

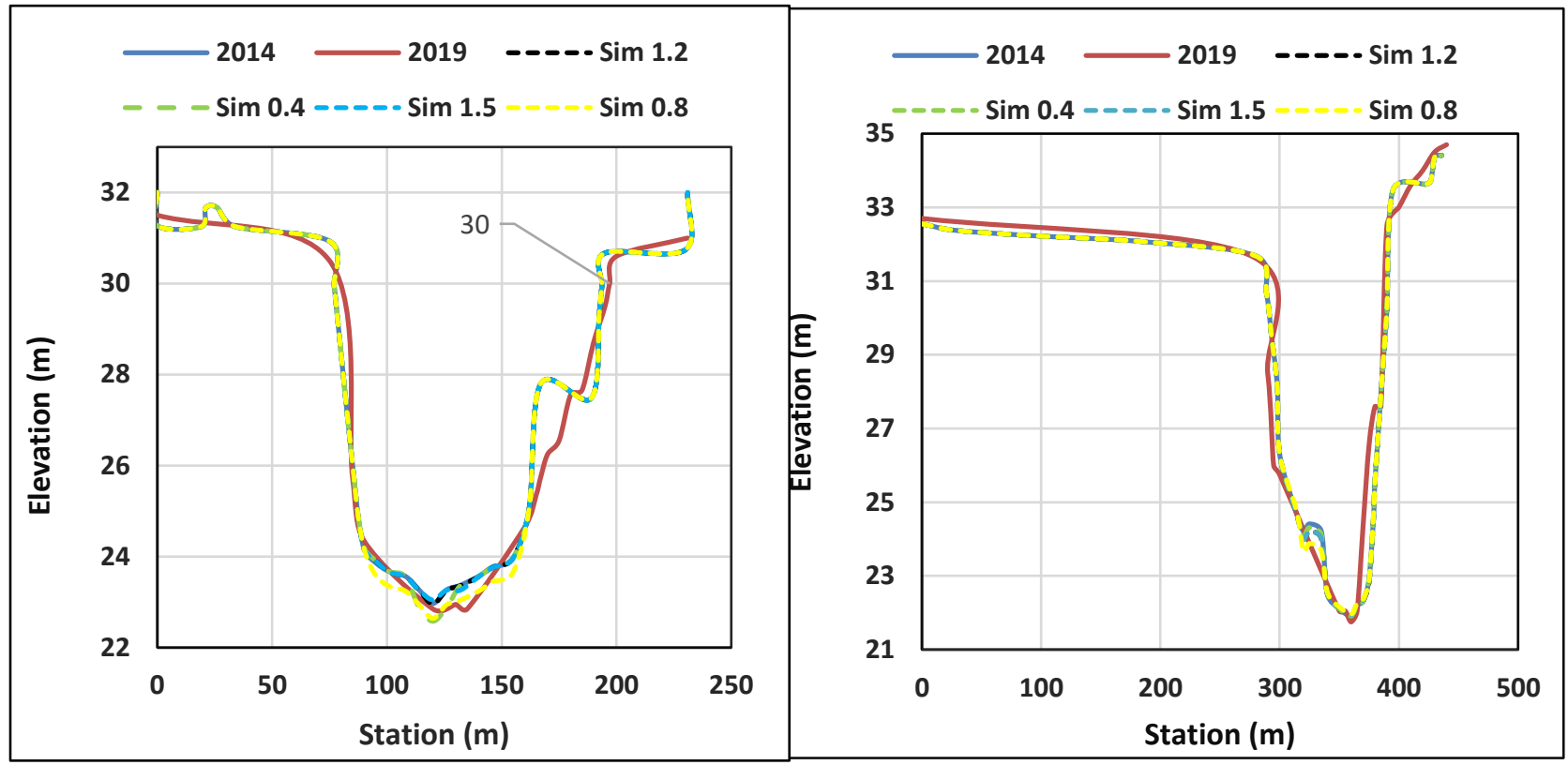

A: C.S $=$ 3.7.Sta $190+500$

B: C.S $=2.71$. Sta $194+00$

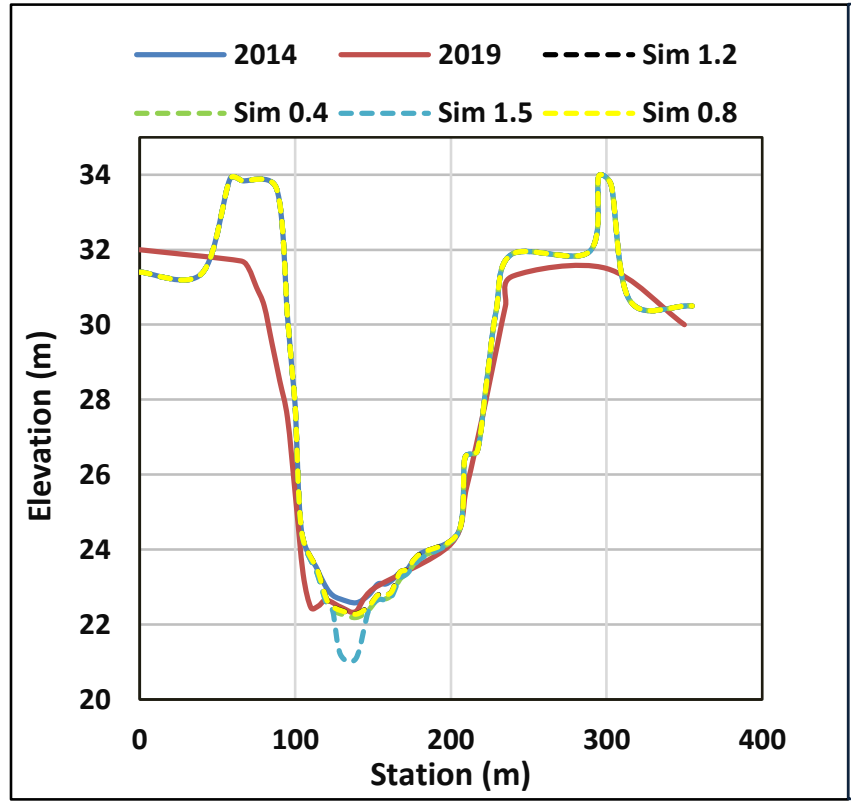

C: C.S $=1.95$. Sta $198+500$

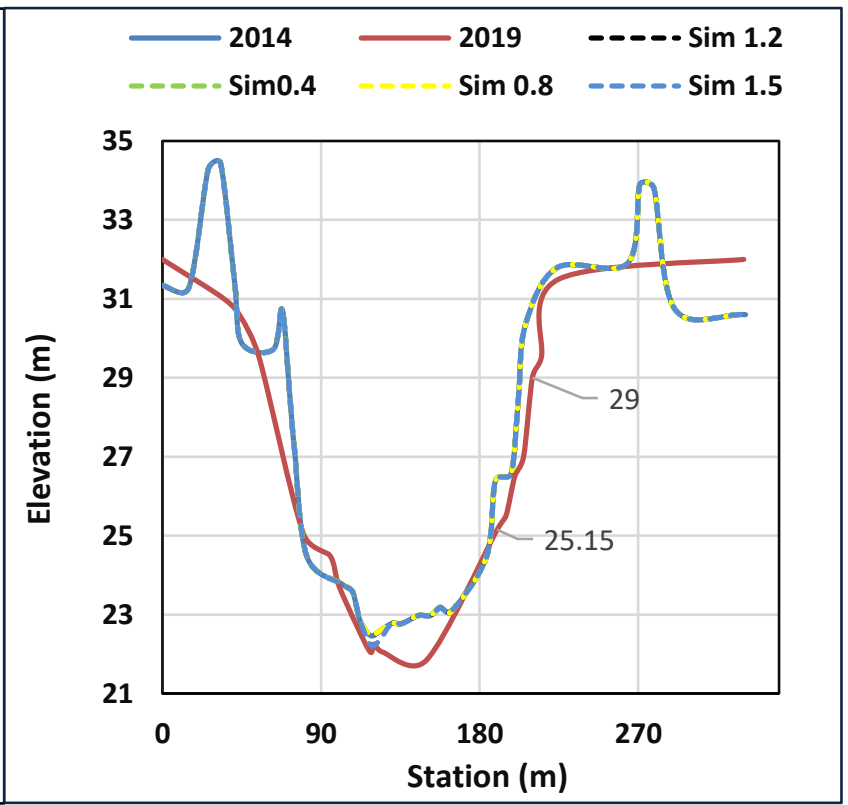

D: C.S $=1.94$. Sta $198+750$

Figure 3. The calibration of the one-dimensional sediment transport model. 


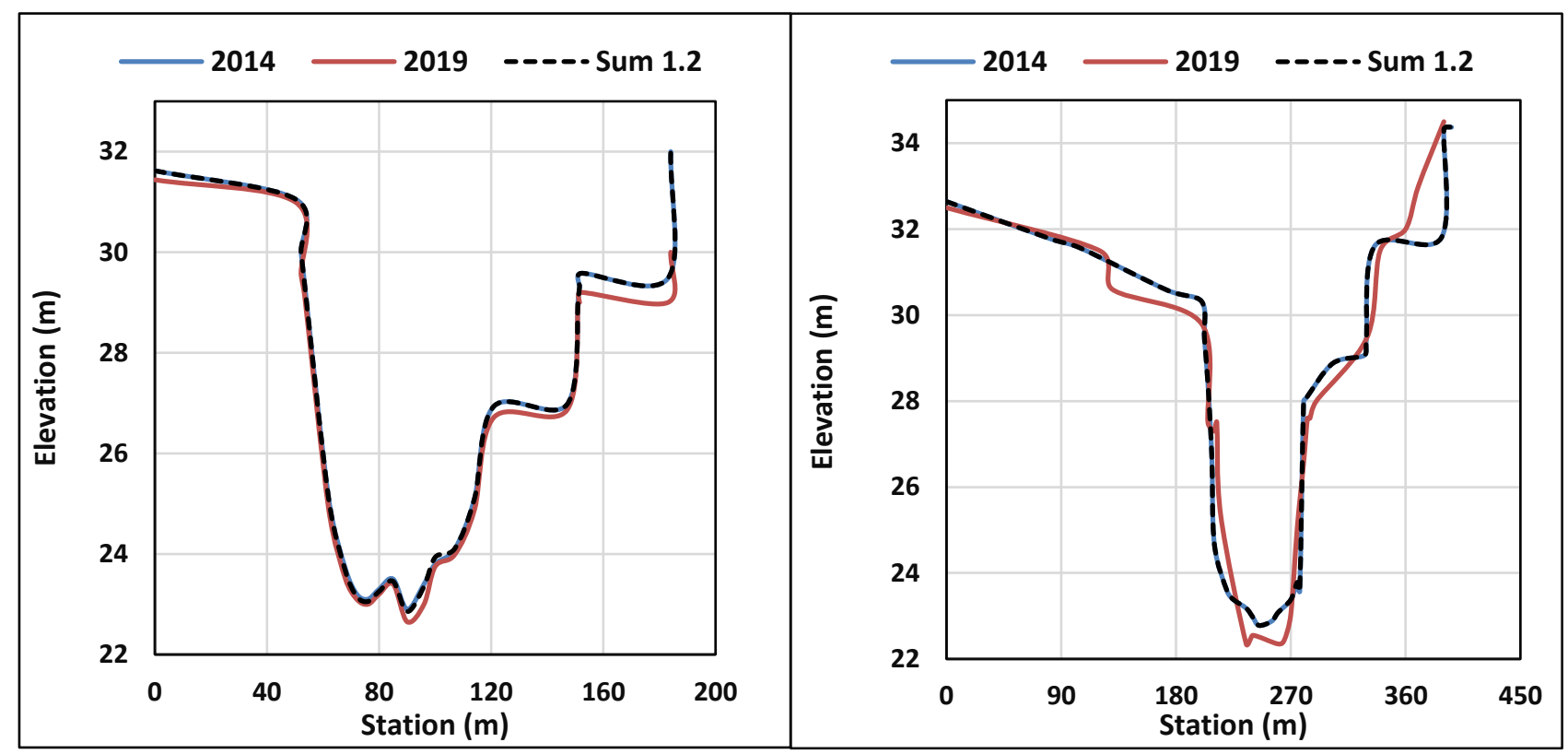
A: C.S $=3.8$. Sta $190+250$
B: C.S=2.7.Sta $194+250$

Figure 4. The validation of the one-dimensional sediment transport model.

\subsection{Simulating the Sediment Transport Model}

After the sediment transport model had been calibrated and validated, a few scenarios were simulated to represent the Diyala River real condition using the actual flowrate values. Also, hypothetical scenarios have been carried out by taking the same real flowrate values from 2018 to 2019 but simulated at different periods. This section will present the analysis of these developed models that show the effect of sedimentation and erosion along the river and predict the sediment and erosion effects for future events. The used values of flowrates in the simulation of all sediment models ranged from (15 to 601) $\mathrm{m}^{3} / \mathrm{s}$ that represent Diyala River during the normal and high flow conditions, measured from October 2018 to October 2019 by MoWR. The first model simulated the actual state of the Diyala River during the period extended from 1/10/2018 to 1/10/2019, shown in Fig.5. 


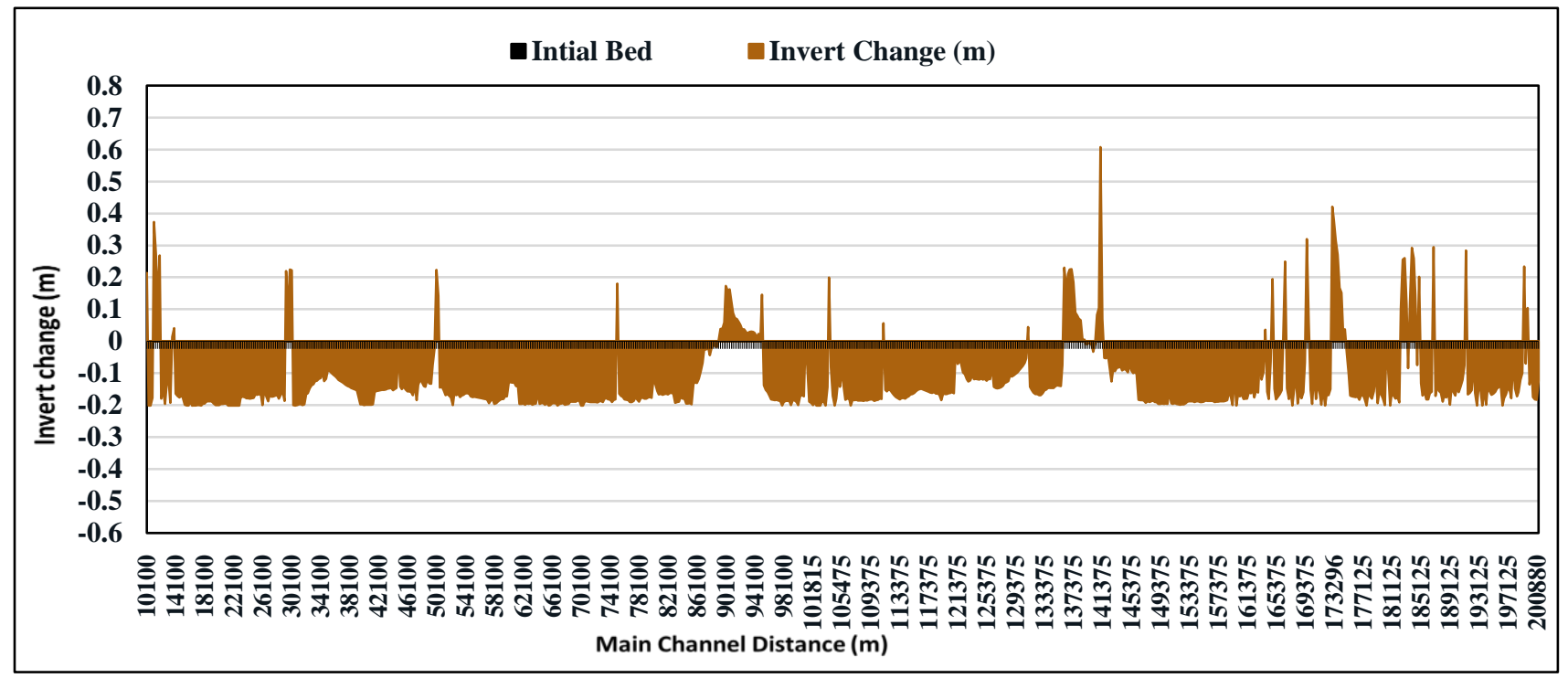

Figure5.The cumulative invert change along the river for one year (1/9/2018-1/9/2019).

The invert change is the initial bed level minus the simulated bed level. If the results are negative, it means erosion. Otherwise, it means sedimentation. When simulating the actual condition of Diyala River for one year, the invert change values ranged from $-0.2 \mathrm{~m}$ to $0.6 \mathrm{~m}$, the maximum deposition depth value was equal to $60 \mathrm{~cm}$, at station $141 \mathrm{~km}$, located downstream of Diyala River. At the same time, the deposition depth value upstream of the river was equal to $38 \mathrm{~cm}$. Also, the values of erosion depths along the river profile were ranged between 5 and $20 \mathrm{~cm}$.

The second model was a hypothetical model which simulated the Diyala River during a period extended from 1/10/2018 to 1/10/2020, using the same flowrate values, shown in Fig.6.

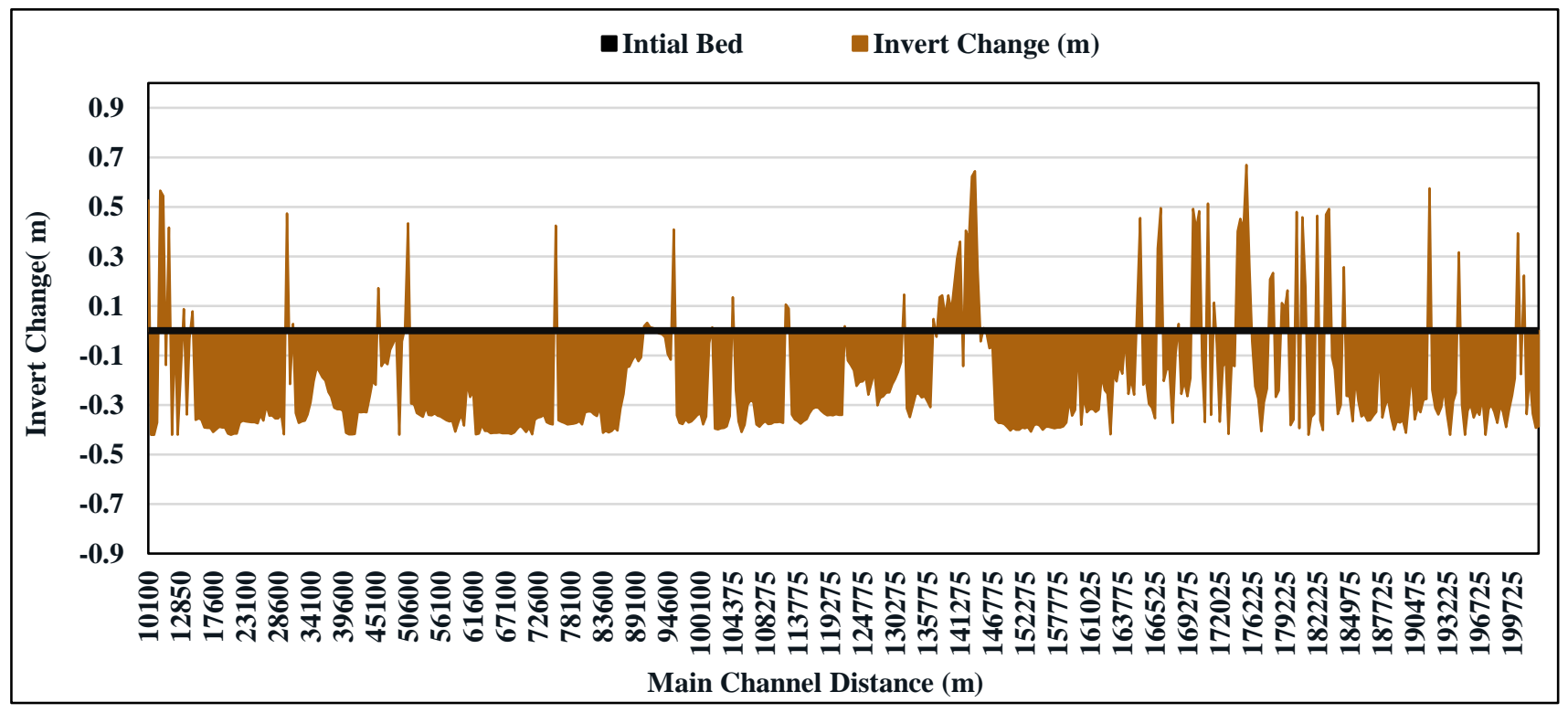

Figure 6. The cumulative invert change along the river for two years (1/1/2018-1/1/2020). 
Fig. 6 shows the invert change values when simulating the Diyala River for two years. The invert change values ranged from $-0.4 \mathrm{~m}$ to $0.66 \mathrm{~m}$. The maximum deposition depth value was equal to $66 \mathrm{~cm}$ at station $175 \mathrm{~km}$, located downstream of Diyala River, and the sedimentation depth value for upstream of the river was equal to $55 \mathrm{~cm}$. Moreover, the erosion depth values along the river ranged from $10 \mathrm{~cm}$ to $40 \mathrm{~cm}$.

The third model was hypothetical that simulated the Diyala River for the imposed period as five successive flood years, and the period was from 1/10/2018 to 1/10/2023, Fig.7.

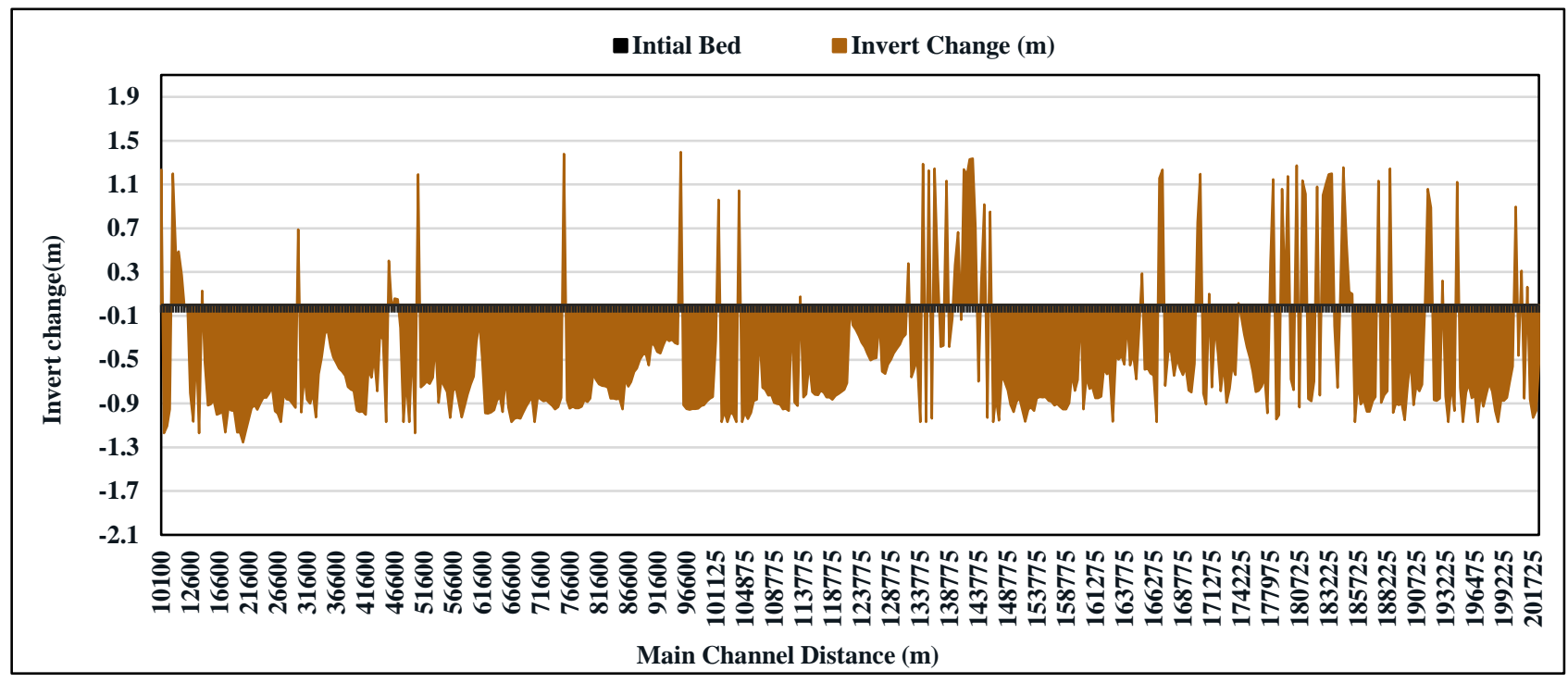

Figure 7. The cumulative invert change along the river for five years (1/1/2018-1/1/2023).

Fig.7 shows the cumulative invert change along Diyala River for five years; the invert change values varied from-1.25 to $1.4 \mathrm{~m}$. The value of maximum sediment depth was $1.4 \mathrm{~m}$, which was located in the center of the river, at station $94 \mathrm{~km}$, and the deposit depth value upstream of the river was equal to $1.2 \mathrm{~m}$. The erosion depth values were ranged from $10 \mathrm{~cm}$ to $1.25 \mathrm{~m}$.

\subsubsection{Sediment quantity in Diyala River}

The sediment transport model was operated by using hydraulic information for the year (20182019) to calculate sediment discharge in the Diyala River, and the results of the model were indicated in Table1. These results of the present study were compared with a previous study (AlAnsari, et al., 1986). There was a difference between the results of the two studies. This was due to the large climatic changes and shortage of water over the years, the selected methods of managing the water resources between Hamreen dam and Derbandikhan, and water releases from the Diyala Dam, etc. These factors led to the increase in the rates of erosion and deposition as well as the change in the longitudinal slope of Diyala River that varied from $11 \mathrm{~cm} / \mathrm{km}$ (Al-Ansari, et al., 1986) to $18 \mathrm{~cm} / \mathrm{km}$ from the present study. 
Table 1. Sediment discharge in Diyala River for the period from 2018 to 2019.

\begin{tabular}{|c|c|c|c|c|}
\hline Month & $\begin{array}{c}\text { Mean water } \\
\text { flowrate, Q, } \\
\mathbf{m} \text { /s }\end{array}$ & Day & $\begin{array}{c}\text { Sediment } \\
\text { discharge, Qs, } \\
\text { ton/day }\end{array}$ & $\begin{array}{c}\text { Sediment discharge, } \\
\text { Qs, ton/month }\end{array}$ \\
\hline Jun & 104.16 & 30 & 45.40 & 1362.14 \\
\hline July & 93.29 & 31 & 35.00 & 1085.06 \\
\hline Aug. & 49.99 & 31 & 14.73 & 456.68 \\
\hline Sep. & 93.29 & 30 & 51.92 & 1557.73 \\
\hline Oct. & 19.16 & 31 & 46.52 & 1442.13 \\
\hline Nov. & 19.16 & 30 & 14.98 & 449.67 \\
\hline Dec. & 96.44 & 31 & 785.20 & 24341.23 \\
\hline Jan. & 396.28 & 31 & 1097.62 & 94026.28 \\
\hline Feb. & 396.28 & 28 & 326.42 & 2966.77 \\
\hline March & 310.64 & 31 & 95.70 & 2732.79 \\
\hline April & 601.16 & 30 & 91.09 & 3971.60 \\
\hline May & 394.60 & 31 & 128.11 & 6960.99 \\
\hline Average & 214.54 & 30 & 227.72 & \\
\hline
\end{tabular}

The used values of flowrates to simulate the actual condition in the Diyala River were measured by MoWR from Jun 2018 to May 2019 and ranged from 19 to $601 \mathrm{~m}^{3} / \mathrm{s}$. The results showed that the daily sediment quantity varied from 14.73 to 1097.6 tons/day, and the average value of daily sediment discharge was equal to 227.7 tons/day. In contrast, the monthly sediment quantity values ranged between 449.6 and 34026 tons/month, and the mean value of monthly sediment discharge was 6961 tons/month. The yearly sediment discharge was 83531.93 tons/year. The flow rate values in the Diyala River ranged from 4 to $441 \mathrm{~m}^{3} / \mathrm{s}$ that measured from Jun 1984 to May 1985 (AlAnsari, et al., 1986). The value of the daily sediment quantity varied between 1.5 to 561.5 tons/day, and the average value of daily sediment discharge was equal to 178.6 tons/day. The monthly sediment quantity values ranged between 45 and 15723.8 tons/month, and the mean value of monthly sediment discharge was 5335 tons/month. The yearly sediment discharge was 64022.5 tons/year in Diyala River from 1984 to 1985.

When comparing the present study and the previous study conducted by (Al-Ansari, et al., 1986), this study has larger values concerning the daily, monthly, and yearly sediment quantity, which were equal to 227.7 tons/day, 6961 tons/month, and 83531.93 tons/year respectively. These values in previous studies were 178.6 tons/day, 5335 tons/month, and 64022.5 tons/year, respectively.

\section{IMPROVING THE DISCHARGE CAPACITY OF DIYALA RIVER WITHIN BAQUBAH CITY}

The one-dimensional steady-state flow model was simulated with a flowrate value equal to 1300 $\mathrm{m}^{3} / \mathrm{s}$ to increase the capacity of the river to endure the maximum flood wave. The model simulation results are presented in Fig. 8 shows the longitudinal profile of the river before the treatment. 
The flooded parts of the river within Baqubah City were divided into three parts to apply the required treatment. The first part was located upstream of the river reach in north of Baqubah City (from station $70 \mathrm{~km}$ to station $102 \mathrm{~km}$ ), with a length equal to $32 \mathrm{~km}$. The elevation of both sides of the river banks was increased at different parts of the reach distance. This solution was chosen since the dredging process is so difficult in this region of the river. The treatment of this part of the river is illustrated in Table 2.

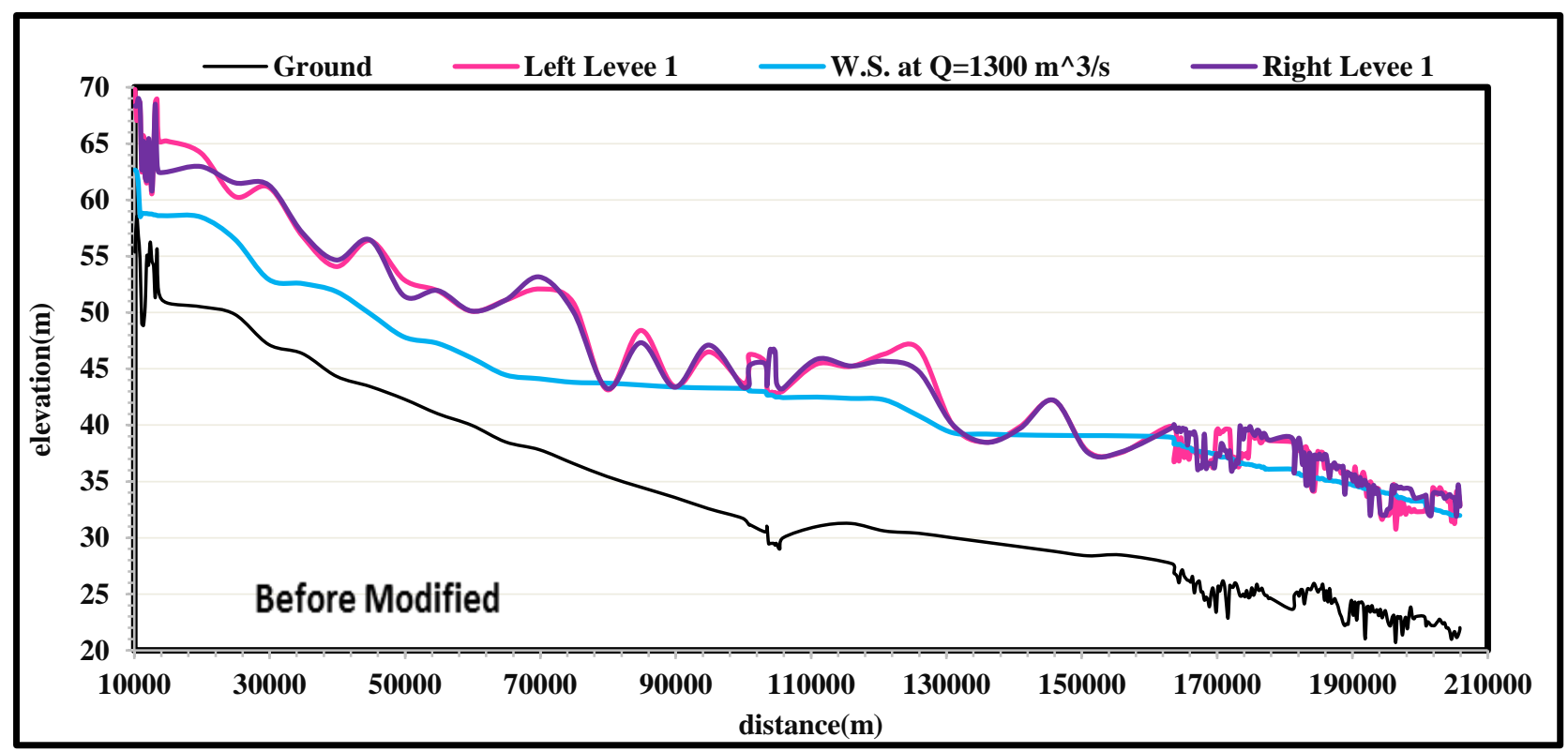

Figure 8. The longitudinal profile of the Diyala River before the treatment.

The second part was in the center of Baquabah City. The area was located between station $100 \mathrm{~km}$ and station $108 \mathrm{~km}$ with a length of $8 \mathrm{~km}$. This region is considered the most important part that needs to be treated since this part is located at the center of the city with a high population, and there are many buildings and bridges along the selected reach of the river. For that reason, the applied treatment for this part is the combination of both dredging and increasing the elevation of some parts of the levee from the left side to pass the maximum flood discharge within this reach. Table 2 illustrates the treatment results for increasing the elevation of the riverbank for the selected station in the center of Baqubah. Table3 illustrates the dredging treatment of the stations located in the center of Baqubah City. The third part was located downstream of Baqubah City between station $108 \mathrm{~km}$ to station $172 \mathrm{~km}$, with a total length of $64 \mathrm{~km}$. The elevation of both sides of the riverbank was increased to treat this part of the river because there was a levee on both sides of the river. The treatment of the downstream part of Baqubah City is presented in Table 2. 
Table 2. Increasing elevations of the riverbank for selected stations within Baqubah City.

\begin{tabular}{|c|c|c|c|c|c|l|}
\hline C.S & Sta1 & Sta2 & Dis & L.Levee & R.Levee & Location \\
\hline 27 & 80000 & 85000 & 5000 & 1.5 & 1.5 & U/S of Baqubah \\
\hline 25 & 90000 & 95000 & 5000 & 1 & 1 & U/S of Baqubah \\
\hline 22 & 99000 & 100000 & 1000 & - & 1.5 & Center Baqubah \\
\hline 17 & 126000 & 131000 & 5000 & 0.25 & 0.25 & D/S of Baqubah \\
\hline 16 & 131000 & 136000 & 5000 & 1.75 & 1.75 & D/S of Baqubah \\
\hline 15 & 136000 & 141000 & 5000 & 0.25 & 0.5 & D/S of Baqubah \\
\hline 13 to 12 & 146000 & 156000 & 10000 & 2.5 & 2.5 & D/S of Baqubah \\
\hline $7.9-7.28$ & 162500 & 172250 & 9750 & 1.5 & 1.5 & D/S of Baqubah \\
\hline
\end{tabular}

Table 3. The dredged stations in the center of Baqubah City.

\begin{tabular}{|c|c|c|c|c|c|c|}
\hline C.S & $\begin{array}{c}\text { Bottom. } \\
\text { Width(m) }\end{array}$ & $\begin{array}{c}\text { Top. } \\
\text { Width(m) }\end{array}$ & $\begin{array}{c}\text { Channel } \\
\operatorname{Depth}(\mathbf{m})\end{array}$ & $\begin{array}{c}\text { Side } \\
\text { Slope }\end{array}$ & $\begin{array}{c}\text { Cut } \\
\text { Area }\left(\mathbf{m}^{2}\right)\end{array}$ & $\begin{array}{c}\text { Cut } \\
\text { Volume }\left(\mathbf{m}^{3}\right)\end{array}$ \\
\hline 21.8 & 100 & 147 & 12 & 2 & 391 & 97750 \\
\hline 21.7 & 75 & 125 & 13 & 2 & 325 & 89456 \\
\hline 21.6 & 100 & 180 & 12 & 2 & 373 & 87313 \\
\hline 21.5 & 100 & 166 & 12 & 2 & 389 & 95260 \\
\hline 21.4 & 75 & 167 & 13 & 2 & 237 & 78180 \\
\hline 21.3 & 75 & 140 & 13 & 2 & 385 & 77716 \\
\hline 21.2 & 75 & 119 & 13 & 2 & 405 & 98686 \\
\hline 21.1 & 75 & 126 & 13 & 2 & 380 & 58848 \\
\hline 21.0 & 75 & 126 & 13 & 2 & 311 & 172698 \\
\hline
\end{tabular}

When the treatment was applied at the flooded regions, the capacity within Diyala River has reached a value equal to $1300 \mathrm{~m}^{3} / \mathrm{s}$ and the value of freeboard equal to $1 \mathrm{~m}$ according to the criteria of the Bencol Engineering Consulting Office of the Ministry of Water Resources. Fig. 9 shows the longitudinal profile of Diyala River after the treatment. Fig. 10 and Fig. 11 show some of the treated cross-sections. 
Number $11 \quad$ Volume 27 November $2021 \quad$ Journal of Engineering

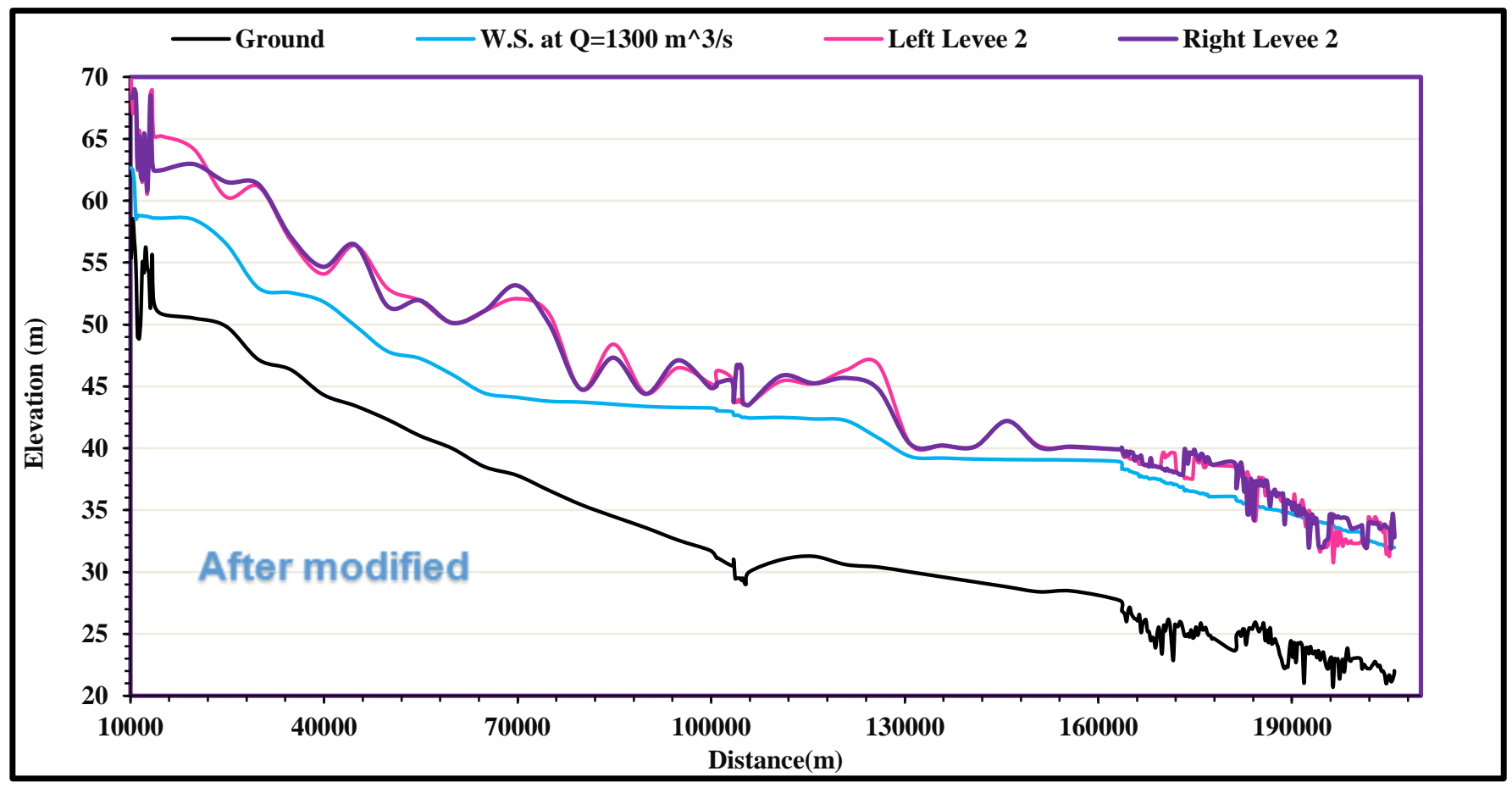

Figure 9. The longitudinal profile of the Diyala River after the treatment.

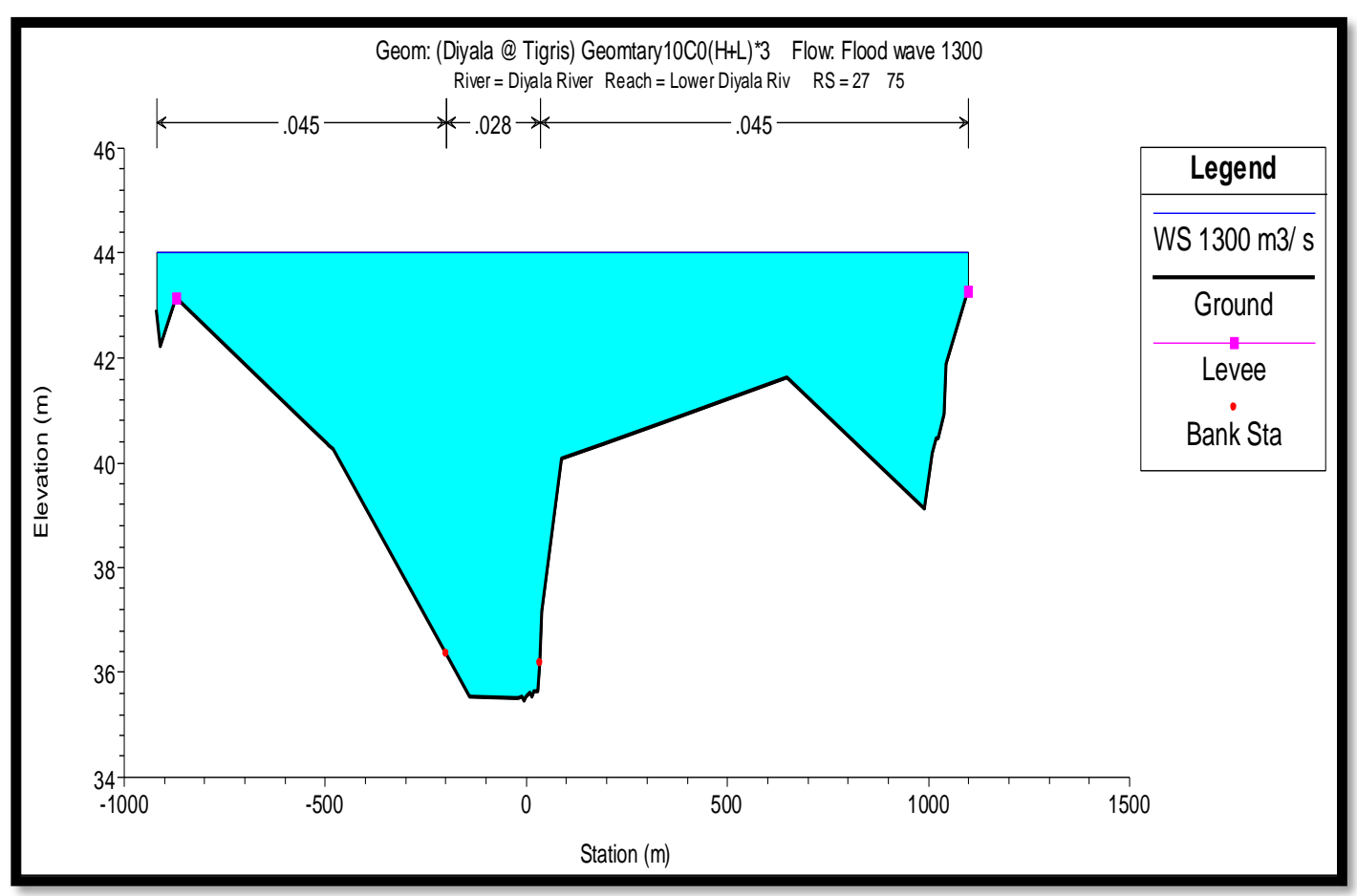

A: cross-section number 27 before the treatment. 


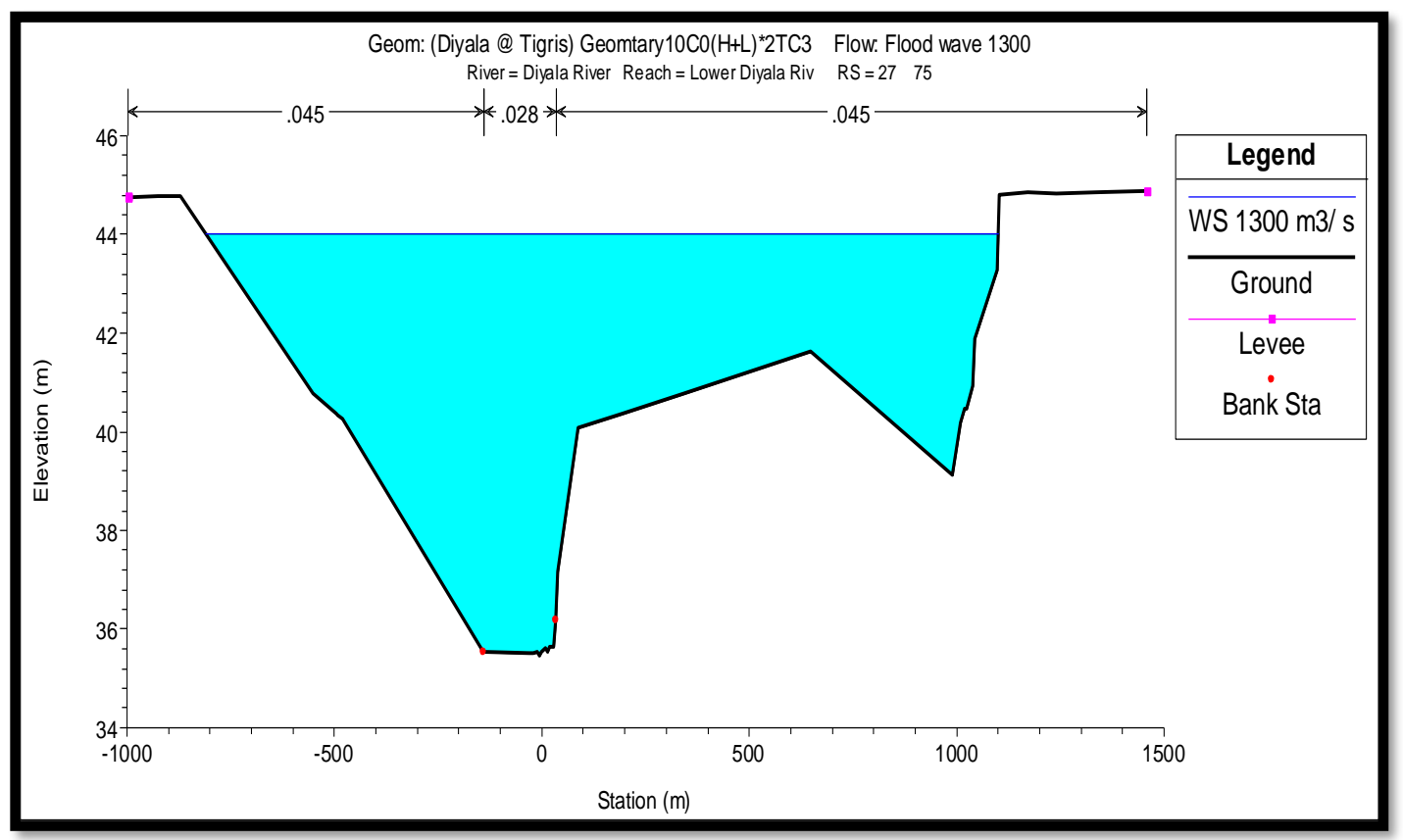

B: cross-section number 27 after the treatment.

Figure 10. The development for the river station upstream of Baqubah City, in (C.S 27).

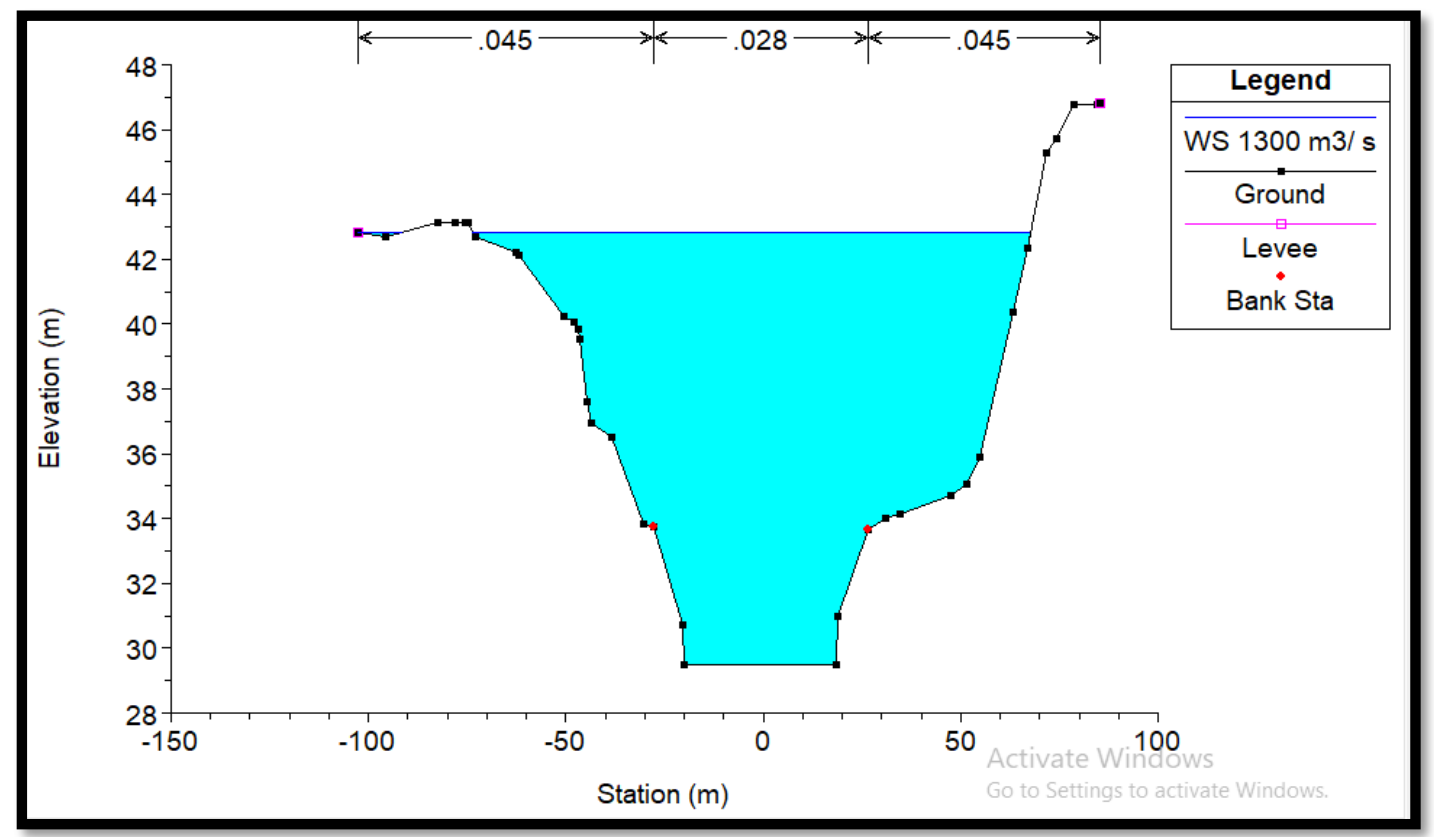

A: cross-section number 21.4 before the treatment. 


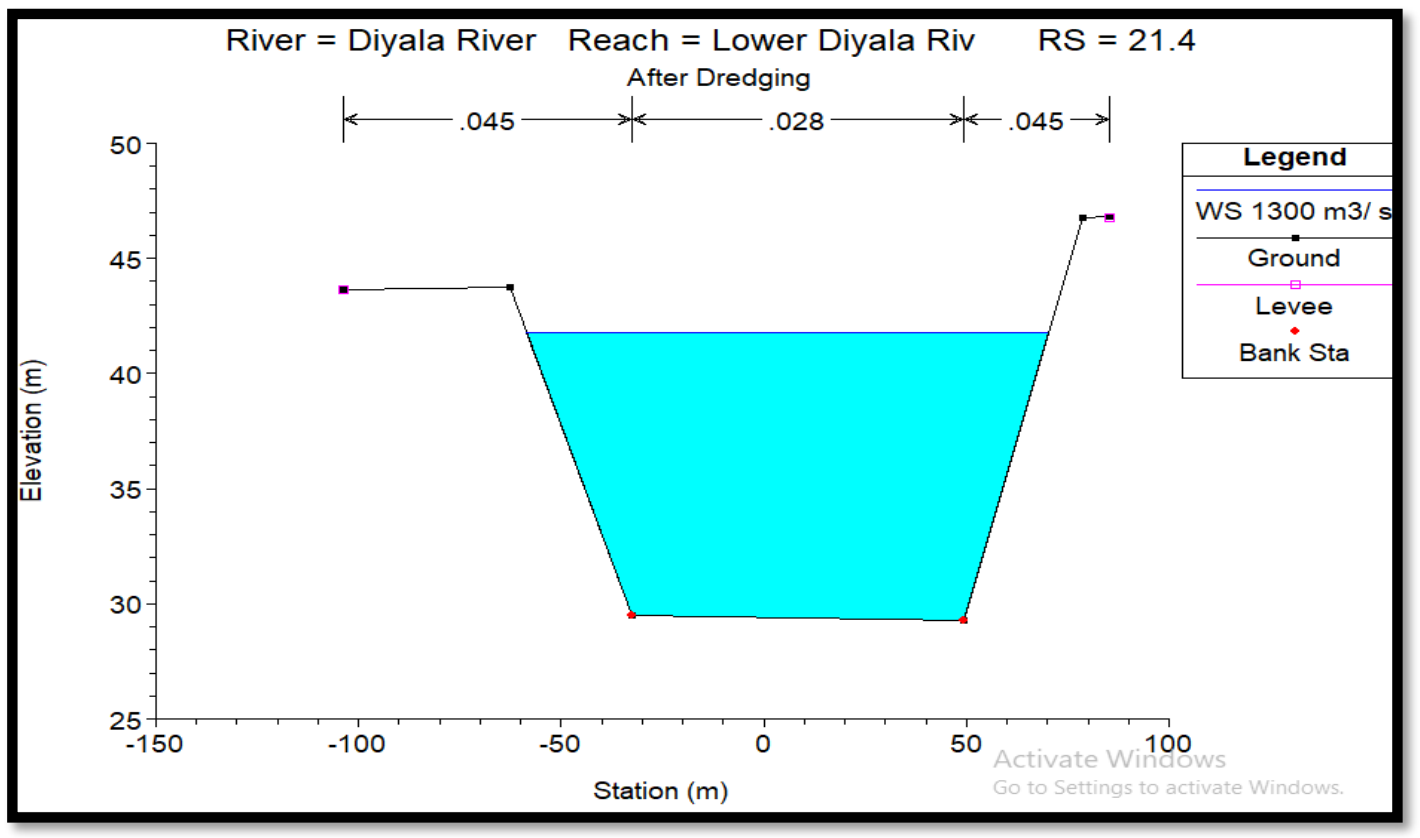

B: cross-section number 21.4 after the treatment.

Figure 11. The development for the river station center of Baqubah City, in (C.S 21.4).

\section{CONCLUSIONS}

From the obtained results of the present study, the following conclusions can be extracted

1. The calibration of the sediment transport model for five years shows that the maximum value of accumulated deposit depth along the river was equal to $120 \mathrm{~cm}$ for five years, which achieves an RMSE and the $\mathrm{R}^{2}$ values of $0.1 \mathrm{~m}$ and 0.87 , respectively.

2. The results of simulating the sediment transport model for representing the actual condition of the lower reach of Diyala River during the period extended from 1/10/2018 to 1/10/2019, the invert change values ranged from $-0.2 \mathrm{~m}$ to $0.6 \mathrm{~m}$

3. The simulation prediction results of the sediment transport model for the imposed period of Diyala River for five years present that the invert change values varied from -1.25 to 1.4 $m$.

4. The estimation of sediment loads for the actual condition in Diyala River from Jun 2018 to May 2019, the daily, monthly, and yearly sediment quantity, were equal to $227.7 \mathrm{ton} /$ day, 6961 ton/month, and 83531.93 tons/year, respectively. These values were greater than the values estimated from previous studies due to climate changes in the region and their effects.

5. The flood issue of the river within Baqubah City was treated by simulating the model with a value of flowrate equal to $1300 \mathrm{~m}^{3} / \mathrm{s}$, and flooded parts were divided into three parts to apply the required treatment. The applied treatment for the first part located in the north of 
Baqubah City increased the elevation of both sides of the river banks at some parts from the main distance. The applied treatment for the second part located in the center of Baqubah City was the combination of both dredging and increasing the elevation of some part of the levee from the left side. The applied treatment for the third part located in the south of Baqubah City increased the elevation of both sides of the river banks.

\section{REFERENCES}

- Al-Ansari, N.A., AL-Sinawi, G.T. and Jamil, A.K., 1986. Suspended and solute loads on the Lower Diyala River, 14 (7), 225-235. Available at: https://iahs.info/uploads/dms/6681.225-235-159-A1-Ansari.pdf.

- Asaad, B., and Abed, B., 2019. Hydraulic characteristics of Tigris River within Baghdad city during drought conditions. Journal of Engineering, 3(26),77-92. Available at: http://www.joe.uobaghdad.edu.iq/.

- Azarang, F., Telvari, A., Sedghi, H., and Bajestan, M.,2015. E valuating of Erosion and Sedimentation of Karkheh River at Downstream. Eco. Env. and Cons,21 (4), 1-13.

- Brunner and Gary W., 2016. HEC-RAS River Analysis System 1D and 2D Modeling User Manual US Army Corps of Engineers Hydrologic Engineering Center.Available at: http://www.hec.usace.army.mil/.

- Daham, M., and Abed, B., 2020. One and Two-Dimensional Hydraulic Simulation of a Reach in Al-Gharraf River. Journal of Engineering, 7(26), 28-44. Available at: http://joe.uobaghdad.edu.iq.

- Daham, M., and Abed, B., 2020. Simulation of Sediment Transport in the Upper Reach of Al-Gharraf River. Materials Science and Engineering,901(1),1-11. Available at: https://iopscience.iop.org/article/10.1088/1757-899X/901/1/012012.

- Kayyun, T., and Dagher, D., 2018. Potential Sediment within a Reach in Tigris River. International Journal of Hydraulic Engineering, 7(2), 22-32.

- Ministry of Water Resources MoWR, 2014-2019. Data on the water levels and hydraulic information of Diyala River.

- Ministry of Water Resources, MoWR. The General Authority for Surveying of the Ministry of Water Resources, 2014-2019. Data on the cross-sections and coordinates of the Diyala River.

- Mustafa, A., Sulaiman, S., and Al-Alwani, K., 2017. Application of HEC-RAS Model to Predict Sediment Transport for Euphrates River from Haditha to Heet. Al-Nahrain Journal for Engineering Sciences (NJES), 20(3), 570-577.

- Mustafa, A., Sulaiman, S., and Shahooth, S., 2016. Application of QUAL2K for Water Quality Modeling and Management in the lower reach of the Diyala river. Iraqi Journal of Civil Engineering,11(2),66-80. 